\title{
The role of a parasite-specific D-site in activation of Plasmodium falciparum cGMP-dependent protein kinase
}

\author{
Eugen Franz ${ }^{1 *}$, Jeong Joo Kim ${ }^{1,2}$, Olga Schneider ${ }^{1}$, Daniela Bertinetti ${ }^{1}$, Choel Kim² ${ }^{2}$, Friedrich W Herberg ${ }^{1}$ \\ From 7th International Conference on cGMP Generators, Effectors and Therapeutic Implications \\ Trier, Germany. 19-21 June 2015
}

\section{Background}

Malaria is one of the most dangerous tropical diseases worldwide, resulting in approximately 1.5-2.7 million deaths per year [1]. Furthermore, malaria belongs to the four major infectious diseases also including HIV, tuberculosis and hepatitis. In humans, malaria is transmitted by four species of the genus Plasmodium. However, most malaria deaths are caused by Plasmodium falciparum [2].

The Plasmodium falciparum cGMP-dependent protein kinase (PfPKG) is one of the key regulators of the malaria parasite life cycle in both sexual and asexual blood-stages. Inhibition of PfPKG stops differentiation and transmission of the parasites, indicating that this kinase is a promising drug target for malaria [3-5]. However, despite its physiological importance, the activation mechanism of PfPKG is not fully understood. Recently, our group discovered that disrupting cGMP binding at the $\mathrm{C}$-terminal cyclic nucleotide-binding (CNB-D) domain almost completely abolishes the kinase activation [6]. Therefore, we investigate the functional role of the PfCNB-D in PfPKG activation.

\section{Results}

To investigate the role of the CNB-D in PfPKG activation, we generated a deletion mutant without the $\mathrm{N}$-terminal 400 amino acid residues $(\Delta 400)$, which is missing a potential auto-inhibitory sequence. We expressed the deletion construct (PfPKG 401-853) containing the catalytic domain and the PfCNB-D in E. coli. For the cGMP binding studies we used fluorescence

\footnotetext{
* Correspondence: franz_eugen@yahoo.de

'Department of Biochemistry, University of University, 34132 Kassel, Germany Full list of author information is available at the end of the article
}

polarization (FP) assay and for the activation studies we used microfluidic mobility-shift assay (MSA).

The deletion construct showed similar affinity for cGMP (40 nM) like the isolated PfCNB-D. In activation, the $\Delta 400$ mutant showed an approximately 3 fold increased activation constant for cGMP $\left(\mathrm{K}_{\mathrm{A}}\right.$ about $240 \mathrm{nM}$ ) in comparison to the full length PfPKG (KA about $70 \mathrm{nM}$ [6]). Unexpectedly, the deletion mutant exhibited a very low basal activity (about $0.3 \mathrm{U} / \mathrm{mg}$ ) in the absence of cGMP. However, it could be activated efficiently by cGMP $(7.0 \mathrm{U} / \mathrm{mg})$, suggesting that the allosteric activation mechanism of PfPKG is dependent only on cGMP binding.

In addition, disrupting cGMP binding through mutating the conserved arginine 492 to lysine (R492K) abolished the cGMP-dependent activation of the deletion mutant (500-600 fold higher $\mathrm{K}_{\mathrm{A}}$ for cGMP), suggesting that the cGMP binding at the CNB-D mainly triggers the activation of this mutant.

\section{Conclusion}

Our results revealed that the activation mechanism of PfPKG differ from mammalian PKGs. Without the autoinhibitory sequence, we expected that the mutant would completely lose its control on the activity, since the catalytic cleft of the kinase is open. However, without cGMP the deletion construct (PfPKG 401-853) has a low basal activity and can be activated efficiently by cGMP. This suggests that controlling PfPKG activity may not depend on the interaction between the inhibitory sequence and the catalytic domain. Upon cGMP binding, conformational changes in the regulatory $(\mathrm{R})$ domain, especially in the area that bridges the regulatory and catalytic domains, induce kinase activation. 


\section{Authors' details}

${ }^{1}$ Department of Biochemistry, University of University, 34132 Kassel,

Germany. ${ }^{2}$ Department of Pharmacology, Baylor College of Medicine, One

Baylor Plaza, Houston, TX, USA.

Published: 2 September 2015

\section{References}

1. World Health Organization: World Malaria Report 2012.

2. Garcia LS: Malaria. Clin Lab Med 2010, 30(1):93-129.

3. Baker DA: Cyclic nucleotide signaling in malaria parasites. Cellular Microbiology 2011, 13(3):331-339.

4. McRobert L, Taylor CJ, Deng W, Fivelman QL, Cummings RM, Polley SD, Billker O, Baker DA: Gametogenesis in Malaria Parasites Is Mediated by the cGMP-Dependent Protein Kinase. PLoS Biol 2008, 6(6):e139.

5. Taylor HM, McRobert L, Grainger M, Sicard A, Dluzewski AR, Hopp CS, et al: The Malaria Parasite Cyclic GMP-Dependent Protein Kinase Plays a Central Role in Blood-Stage Schizogony. Eukaryotic Cell 2010, 9(1):37-45.

6. Kim JJ, Flueck C, Franz E, Sanabria-Figueroa E, Thompson E, Lorenz R, et al: Crystal structures of the carboxyl cGMP binding domain of the Plasmodium falciparum cGMP-dependent protein kinase reveal a novel capping triad crucial for merozoite egress. PLoS Pathog 2015, 11(2): e1004639.

doi:10.1186/2050-6511-16-S1-A51

Cite this article as: Franz et al:: The role of a parasite-specific D-site in activation of Plasmodium falciparum cGMP-dependent protein kinase. BMC Pharmacology and Toxicology 2015 16(Suppl 1):A51.

\section{Submit your next manuscript to BioMed Central and take full advantage of:}

- Convenient online submission

- Thorough peer review

- No space constraints or color figure charges

- Immediate publication on acceptance

- Inclusion in PubMed, CAS, Scopus and Google Scholar

- Research which is freely available for redistribution

Submit your manuscript at www.biomedcentral.com/submit 